\title{
HIPERTIROID PADA KEHAMILAN MOLA HIDATIDOSA
}

\author{
Erwin Pangkahila \\ Karel Pandelaki
}

Bagian Ilmu Penyakit Dalam Fakultas Kedokteran Universitas Sam Ratulangi Manado

\begin{abstract}
We reported a suspected pregnancy associated with 2-month-vaginal bleeding in a 42-year-old female. She was diagnosed with hyperthyroidism associated with mola hydatidosa. The diagnosis of hyperthyroidism was based on anamnesis, and physical, laboratory, and radiological examinations. We found palpitation, weakness, loss of weight, much sweating, tachicardia, and some enlargement of the thyroid glands. The laboratory examination showed an increase of hCG and free T4, in addition to a decrease of TSHs. In the USG examination we found a snow-like pattern. The histopathological examination showed avascularization with hydrophic degeneration of the villi, and cysterna formation, all of which concluded that it was a mola hydatidosa pregnancy. The patient was treated with PTU $100 \mathrm{mg}$ and propanolol $10 \mathrm{mg}$ three times daily for the hyperthyroidism, and a total hysterectomy operation for the mola hydatidosa pregnancy. Prognosis of the patient was dubious.
\end{abstract}

Keywords: hyperthyroid, mola hydatidosa, hCG, FT4, TSHs.

\begin{abstract}
Abstrak: Telah dilaporkan seorang perempuan umur 42 tahun dengan dugaan kehamilan dan mengalami perdarahan jalan lahir sejak dua bulan lalu, yang kemudian didiagnosis dengan hipertiroid pada mola hidatidosa. Diagnosis hipertiroid pada kehamilan mola hidatidosa ditegakkan berdasarkan anamnesa, pemeriksaan fisik, laboratorium dan radiologi. Ditemukan gejala jantung berdebar, kelemahan badan, penurunan berat badan dan berkeringat banyak, serta tanda takikardi dan pembesaran ringan kelenjar tiroid. Pemeriksaan laboratorium terdapat peningkatan kadar hCG dan T4 bebas serta penurunan kadar TSHs. Pemeriksaan USG tampak gambaran snow-like pattern dan histopatologi terdapat vili yang alami degenerasi hidropik, avaskuler dengan pembentukan sisterna yang menyimpulkan suatu kehamilan mola hidatidosa. Pengobatan dengan pemberian PTU $100 \mathrm{mg}$ dan propanolol $10 \mathrm{mg}$, kedua-duanya tiga kali sehari untuk penanganan hipertiroid, serta dilakukan tindakan operasi histerektomi totalis untuk penanganan kehamilan mola hidatidosanya. Prognosis penderita adalah dubia.
\end{abstract}

Kata kunci: hipertiroid, mola hidatidosa, hCG, FT4, TSHs.

Hipertiroid adalah hiperfungsi kelenjar tiroid, berupa peningkatan biosintesis dan sekresi hormon oleh kelenjar tiroid. ${ }^{1}$ Salah satu penyebab sekunder terjadinya hipertiroid adalah kehamilan mola yang termasuk dalam penyakit trofoblastik gestasional., ${ }^{2,3}$ Mola hidatidosa tergolong dalam penyakit trofoblas, dan merupakan kehamilan yang berkembang tidak normal. ${ }^{1}$

Insiden penyakit trofoblas ini sangat bervariasi antar negara di dunia. Di Jepang dilaporkan insiden penyakit ini dua dari
1000 kehamilan, dan tiga kali lebih tinggi dari insiden di Eropa dan Amerika Utara. Angka kejadian di Indonesia sendiri dilaporkan satu kehamilan mola diantara 85375 kehamilan. ${ }^{1,2,4}$ Frekuensi hipertiroid pada kehamilan mola diperkirakan antara lima sampai $64 \% .^{5}$

Penyebab hipertiroid pada kehamilan mola hidatidosa akibat peningkatan kadar human Chorionic Gonadotropin (hCG). Kadar hCG yang tinggi ini berefek stimulasi terhadap kelenjar tiroid, sehingga terjadi 
peningkatan kadar hormon tiroid dalam serum yang menyebabkan terjadinya tirotoksikosis. $^{6-8}$

Gejala klinis bervariasi dari asimptomatis sampai krisis tiroid. Manifestasi klinis dapat berupa kelemahan badan, penurunan berat badan, kelemahan otot, tidak tahan terhadap panas, berkeringat banyak, takikardi dan pembesaran kelenjar tiroid yang minimal. ${ }^{9,10}$

Pemeriksaan laboratorium yang diperlukan adalah pemeriksaan kadar hCG, kadar Free $\mathrm{T}_{4}\left(\mathrm{FT}_{4}\right)$ dan Thyroid Stimulating Hormone (TSH) untuk hipertiroid. Pemeriksaan penunjang lainnya yang dibutuhkan adalah USG, foto toraks, dan pemeriksaan histopatologik untuk mendiagnosis suatu kehamilan mola. ${ }^{11-13}$

Diagnosis ditegakkan berdasarkan anamnesa, pemeriksaan fisik, dan pemeriksaan laboratorium, serta pemeriksaan penunjang. ${ }^{1}$

Penanganan kasus ini mencakup penanganan terhadap hipertiroid dan kehamilan mola hidatidosa. Keadaan hipertiroid sekunder ini akan secara cepat membaik setelah evakuasi jaringan mola.,14

Berikut ini akan dilaporkan sebuah kasus hipertiroid pada kehamilan mola hidatidosa yang dirawat di RSU Prof Dr RD Kandou Manado.

\section{LAPORAN KASUS}

Seorang perempuan berusia 42 tahun dikonsulkan dari Bagian Kebidananan dan Kandungan dengan diagnosis kehamilan mola hidatidosa disertai suspek hipertiroid untuk rawat bersama dalam penanganan selanjutnya. Data penderita lainnya adalah pekerjaan ibu rumah tangga, alamat di Tuminting Manado, masuk rumah sakit dengan keluhan perdarahan jalan lahir yang sudah dialami sejak dua bulan yang lalu. Perdarahan terjadi sedikit demi sedikit dan hilang timbul. Penderita memerlukan pembalut perempuan satu sampai dua kali setiap harinya. Penderita sebelumnya mengetahui bahwa ia sedang hamil anak ketiga melalui pemeriksaan air seni dengan menggunakan pemeriksaan stik tiga bulan yang lalu. Keluhan ini mendorong penderita untuk berobat ke Puskesmas. Setelah beberapa hari berobat di Puskesmas penderita tidak merasa terjadi perbaikan, sehingga ia dirujuk ke RSU Prof. Dr. R.D. Kandou. Penderita juga mengeluh jantung berdebar, sering rasa mual dan muntah, penurunan berat badan, kelemahan badan, berkeringat banyak, serta pembesaran leher yang ringan. Jantung berdebar dirasakannya sejak dua bulan lalu dan timbul walaupun ia dalam keadaan istirahat. Berat badannya turun tiga $\mathrm{kg}$ dalam tiga bulan terakhir. Pembesaran leher dirasakannya sejak satu bulan lalu. Pembesaran hanya ringan saja dan penderita tidak mengalami kesukaran dalam proses menelan makanan atau minum air. Tidak terdapat gangguan dalam buang air besar dan buang air kecil.

Pada pemeriksaan fisik ditemukan keadaan umum tampak sakit sedang, kesadaran kompos mentis, tinggi badan $155 \mathrm{~cm}$, berat badan $46 \mathrm{~kg}$. Tekanan darah 150/90 $\mathrm{mmHg}$, nadi $108 \mathrm{x} / \mathrm{menit}$ teratur, pernafasan $24 \mathrm{x} /$ menit, dan suhu badan $37,8^{0} \mathrm{C}$. Konjungtiva tidak pucat, sklera tidak ikterus, faring tidak hiperemis, dan tidak ada pembesaran tonsil. Pada leher, pembesaran kelenjar tiroid dengan ukuran kira-kira 2 X 3 $\mathrm{cm}$, konsistensi lunak, difus, tidak nyeri pada penekanan, tekanan vena jugularis $5+1$ $\mathrm{cm} \mathrm{H}_{2} \mathrm{O}$, dan tidak terdapat pembesaran kelenjar getah bening. Dada tampak simetris kiri dan kanan, fremitus raba normal, perkusi sonor, batas paru hati pada ruang antar iga IV, suara nafas vesikuler, dan tidak terdapat ronki maupun mengi. Pada pemeriksaan jantung, iktus kordis tampak, teraba di ruang antar iga $\mathrm{V}$ garis mid klavikula kiri. Suara jantung pertama dan kedua normal, regular, dan tidak terdapat bising. Pada pemeriksaan abdomen didapatkan perut tampak cembung, hati dan limpa tidak teraba, bising usus normal, dan tinggi fundus uteri satu $\mathrm{cm}$ bawah umbilikus. Ekstremitas teraba hangat, tidak ditemukan tremor, dan tidak didapatkan adanya edema.

Pada pemeriksaan laboratorium saat masuk rumah sakit didapatkan kadar hemoglobin $11.8 \mathrm{~g} / \mathrm{dL}$, leukosit 10.400/uL, trom- 
bosit 313.000/uL, GDS $79 \mathrm{mg} / \mathrm{dL}$, ureum 34 $\mathrm{mg} / \mathrm{dL}$, kreatinin $0.7 \mathrm{mg} / \mathrm{dL}$, SGOT $26 \mathrm{u} / \mathrm{L}$, SGPT $28 \mathrm{u} / \mathrm{L}$, waktu perdarahan dua menit, waktu pembekuan 10 menit. Pemeriksaan endokrin kadar serum TSHs 0,016 $\mu \mathrm{IU} / \mathrm{ml}$, $\mathrm{FT}_{4}$ 4,15 ng/dl dan kadar $\beta$ hCG 596.236 $\mathrm{mIU} / \mathrm{ml}$. EKG menunjukkan sinus takikardi. Foto toraks posisi antero-posterior tidak menunjukkan kelainan, dan hasil USG menunjukkan tidak tampak kantung janin melainkan tampak gambaran vesikuler di seluruh kavum uteri dan snow-like pattern yang menyimpulkan suatu kehamilan mola hidatidosa.

Berdasarkan anamnesis, pemeriksaan fisik, laboratorium, dan radiologi, maka ditegakkan diagnosis hipertiroid pada kehamilan mola hidatidosa

Penanganan penderita berupa pemberian Propiltiourasil (PTU) $100 \mathrm{mg}$ tiga kali sehari dan Propanolol $10 \mathrm{mg}$ tiga kali sehari dan tindakan operatif histerektomi serta transfusi PRC 230 cc sebanyak dua kantong selama operasi.

Pada hari ketiga perawatan, keadaan umum sedang, kesadaran kompos mentis. Keluhan jantung berdebar telah berkurang. Tekanan darah 140/80 mmHg, nadi 96x/ menit, respirasi $20 \mathrm{x} /$ menit, dan suhu badan $37,2^{\circ} \mathrm{C}$. Hasil pemeriksaan laboratorium didapatkan $\mathrm{Hb} 10.9 \mathrm{~g} / \mathrm{dL}$, leukosit 11.000/ $\mathrm{uL}$, dan trombosit 342.000/uL. Hasil pemeriksaan histopatologi menunjukkan gambaran vili korealis berukuran besar dan berbentuk bulat, mengalami degenerasi hidropik, avaskuler, dengan pembentukan sisterna, kesemuanya ini menyimpulkan suatu kehamilan mola hidatidosa.

Pada hari keempat perawatan, keadaan umum sedang, kesadaran kompos mentis, keluhan jantung berdebar tidak ada lagi. Tekanan darah 120/80 mmHg, nadi $88 \mathrm{x} / \mathrm{me}$ nit, respirasi $20 \mathrm{x} / \mathrm{menit}$, dan suhu badan $36,6^{\circ} \mathrm{C}$. Penderita kemudian dipulangkan dan dianjurkan kontrol di poliklinik endokrin dan poliklinik ginekologi.

\section{PEMBAHASAN}

Trophoblastic hyperthyroidism, yang dikenal dengan hipertiroid pada penyakit trofoblastik, dimana termasuk didalamnya adalah kehamilan mola dan penyakit tropoblastik yang persisten. Mola hidatidosa adalah suatu penyakit trofoblas dan merupakan kehamilan yang tidak normal, ditandai oleh kelainan plasenta berupa proliferasi sel-sel trofoblas serta degenerasi hidrofik dari vili korealis. ${ }^{1}$

Angka kejadiannya di Indonesia dan negara berkembang sangat tinggi dibandingkan dengan negara maju. Data rumah sakit di Indonesia menunjukkan satu kehamilan mola diantara 85-375 kehamilan.,2,4 Frekuensi hipertiroid pada kehamilan mola diperkirakan antara 5 sampai $64 \% .^{5}$ Parazzini dkk. melaporkan bahwa risiko tersebut meningkat dua kali lebih tinggi pada perempuan diatas 35 tahun, dan 7,5 kali lebih tinggi pada perempuan diatas 40 tahun. ${ }^{2}$ Pada kasus ini ditemukan perempuan berusia 42 tahun dengan hipertiroid pada kehamilan mola hidatidosa.

Patofisiologi terjadinya hipertiroid pada kehamilan mola hidatidosa adalah terjadinya peningkatan kadar serum hCG yang mempunyai efek stimulasi tiroid. ${ }^{1,15}$ Pada trimester pertama kehamilan normal, kadar hCG akan mencapai puncak, sedangkan kadar TSH serum akan turun sampai kadar yang rendah. Pada kehamilan normal, sebagian besar penurunan kadar TSH serum ini tidak berlangsung lama. Pada keadaan patologi dimana kadar hCG meningkat secara bermakna untuk waktu yang cukup lama, maka akan terjadi stimulasi kelenjar tiroid secara bermakna pula. Keadaan ini akan menyebabkan penurunan kadar TSH dan peningkatan kadar hormon bebas. Hormon hCG dan TSH merupakan hormon yang termasuk dalam kelompok hormon glikoprotein yang mengandung subunit $\alpha$ dan subunit $\beta$. Subunit $\beta$ pada hormon hCG dan hormon TSH $85 \%$ memiliki kesamaan pada 114 asam amino pertama. Persamaan ini menyebabkan terjadi stimulasi berlebihan hCG terhadap reseptor TSH pada kelenjar tiroid untuk memproduksi hormon tiroksin dan triodotironin. ${ }^{5,15}$

Gejala klinis tirotoksikosis dapat di- 
jumpai pada mola hidatidosa dengan beberapa sifat yang istimewa, yaitu sering tidak menunjukkan gambaran klinis tirotoksikosis yang umum, walaupun hasil pemeriksaan laboratorium jelas menunjukkan keadaan hipertiroid. Hal ini menyebabkan keadaan tersebut seringkali tidak terdiagnosis. ${ }^{1}$ Gejala klinis yang kurang nyata ini disebabkan oleh karena sekresi berlebihan hormon tiroid hanya terjadi dalam waktu yang singkat saja, atau karena gejala dan tanda tirotoksikosis ini tersamar oleh gejala dan tanda penyakit tropoblastik ini. $^{15}$ Perjalanan penyakitnya dapat timbul secara cepat atau dapat tiba-tiba muncul sebagai keadaan yang sangat berat. Keadaan sangat berat tersebut dapat berupa krisis tiroid atau gagal jantung mendadak. ${ }^{1}$ Gejala dan tanda klinis tirotoksikosis yang dapat timbul adalah berkeringat banyak, tidak tahan terhadap panas, palpitasi, sesak nafas, kelemahan badan, penurunan berat badan, nafsu makan bertambah, pembesaran kelenjar tiroid yang ringan, tremor, takikardi, dan fibrilasi atrial. ${ }^{15}$ Pada kasus ini ditemukan gejala jantung berdebar, kelemahan badan, penurunan berat badan, dan berkeringat banyak, serta tanda takikardi dan pembesaran ringan kelenjar tiroid.

Pemeriksaan laboratorium yang diperlukan pada hipertiroid dengan kehamilan mola adalah pemeriksaan kadar hormon $\beta \mathrm{hCG}, \mathrm{FT}_{4}$ dan TSHs. Hipertiroid pada kehamilan mola ditunjukkan dengan peningkatan kadar $\mathrm{FT}_{4}$ dan $\mathrm{FT}_{3}$, penurunan TSHs dan peningkatan hCG yang sangat bermakna. 5 Peningkatan kadar hCG yang sangat tinggi mencapai 1000 kali dari nilai normal. Pada penyakit trofoblastik kadar hCG umumnya melebihi 300.000 IU/L, dan selalu melebihi $100.000 \mathrm{IU} / \mathrm{L} .{ }^{16}$ Rasio $\mathrm{T}_{3}: \mathrm{T}_{4}$ pada kehamilan mola sangat rendah, tidak seperti pada penyakit Grave's yang sering lebih besar dari dua puluh. ${ }^{3,17}$ Penelitian yang dilakukan oleh Glinoer menyimpulkan bahwa setiap kenaikan kadar hCG sebesar $10.000 \mathrm{IU} / \mathrm{L}$ akan meningkatkan kadar $\mathrm{T}_{4}$ sebesar 0,1ng/dl, dan menurunkan kadar TSH sebesar 0,1 mIU/L. Peningkatan kadar serum $\mathrm{T}_{4}$ akan terjadi hanya bila konsentrasi
hCG > 50.000 IU/L, dan menetap lebih dari satu minggu. ${ }^{5}$ Pada kasus ini ditemukan peningkatan kadar hCG, $\mathrm{T}_{4}$ bebas, dan penurunan kadar TSHs.

Pemeriksaan penunjang yang diperlukan untuk menegakkan diagnosis adalah pemeriksaan USG dan histopatologi. Pemeriksaan USG menunjukkan tidak tampak kantung janin, tampak gambaran vesikuler di seluruh kavum uteri, dan snow-like pattern yang menyimpulkan suatu kehamilan mola hidatidosa. Pemeriksaan histopatologi menunjukkan gambaran vili korealis berukuran besar dan berbentuk bulat, mengalami degenerasi hidropik, avaskuler, disertai pembentukan sisterna yang menyimpulkan suatu kehamilan mola hidatidosa (Gambar 1).

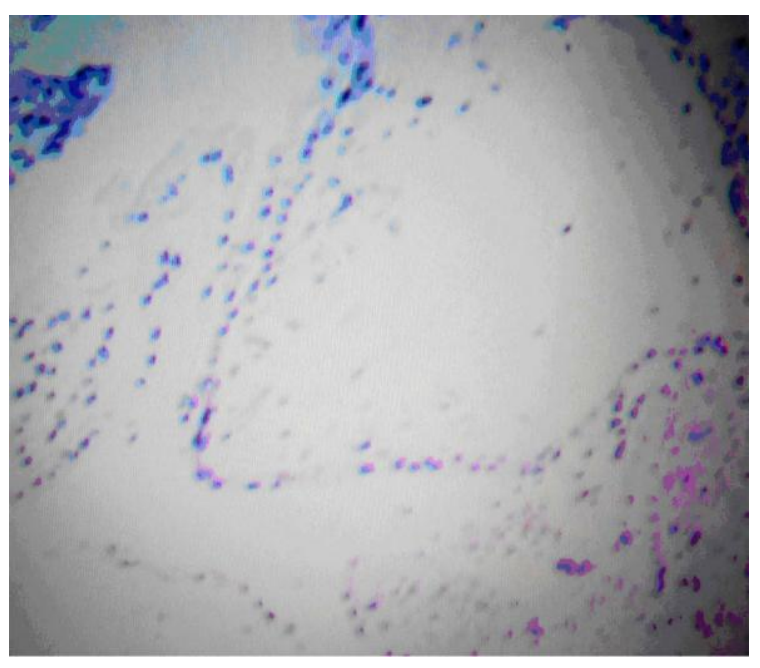

Gambar 1. Foto histopatologis penderita

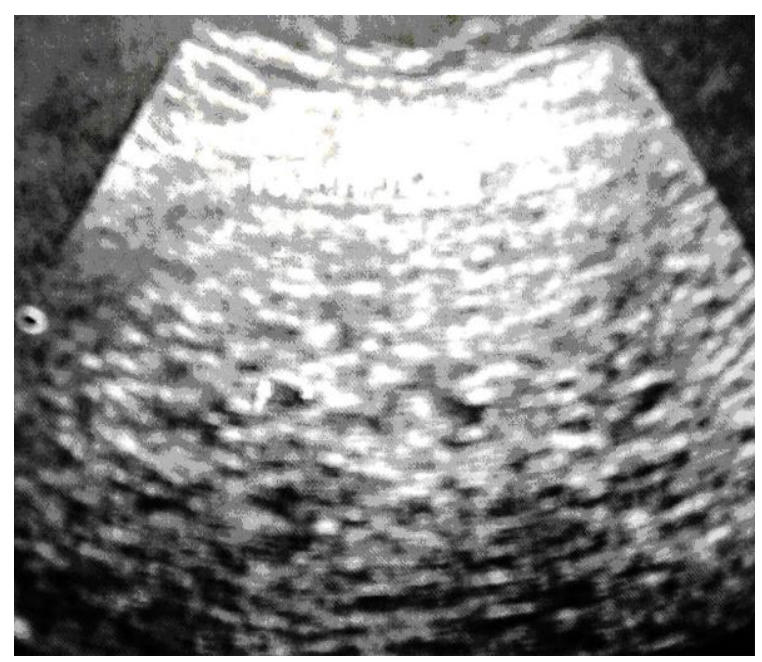

Gambar 2. Foto USG penderita 
Pada kasus ini hasil USG menunjukkan gambaran snow like pattern. Selain itu hasil pemeriksaan histopatologi menunjukkan gambaran degenerasi hidropik dari vili korealis, yang menyimpulkan suatu kehamilan mola hidatidosa (Gambar 2).

Diagnosis tirotoksikosis pada mola hidatidosa dapat ditegakkan dan dipastikan dengan pemeriksaan kadar hormon tiroid bebas, yaitu $\mathrm{FT}_{4}$, dan TSH yang sangat rendah. Indeks Wayne tidak selalu dapat dijadikan pegangan. Nilai indeks Wayne yang rendah tidak menyingkirkan tirotoksikosis pada kehamilan mola hidatidosa. Hal-hal khusus yang dapat mengarahkan ke dugaan yang kuat adalah frekuensi nadi, besarnya uterus, dan kadar hCG. Nadi yang $\geq 100 \mathrm{X} /$ menit tanpa sebab lain yang dapat diterangkan memiliki sensitivitas $100 \%$ dan spesifisitas 32\%. Besarnya uterus dengan tinggi fundus uteri yang lebih besar dari kehamilan 20 minggu mempunyai sensitivitas $73 \%$ dan spesifisitas $100 \%$. Kadar hCG $\geq$ $300.000 \mathrm{mIU} / \mathrm{ml}$ memiliki sensitivitas $100 \%$ dan spesifisitas $85 \% .^{1}$ Pada kasus ini diagnosis hipertiroid pada kehamilan mola hidatidosa ditegakkan berdasarkan kadar $\mathrm{FT}_{4}$ yang tinggi, kadar TSHs yang rendah, tingginya kadar hCG, serta hasil pemeriksaan USG dan histopatologi yang mendukung kearah suatu kehamilan mola hidatidosa. Nilai indeks Wayne pada penderita ini adalah 16.

Penanganan hipertiroid pada kehamilan mola adalah pada saat diagnosis ditegakkan perlu segera diberikan terapi. Mengingat tirotoksikosis dapat mendadak menjadi berat, maka pada saat diagnosis ditegakkan sedini mungkin diberikan pengobatan PTU 100 mg tiga kali sehari, dan menjelang tindakan kuretase ditambahkan larutan Lugol 10 tetes tiap delapan jam. Bila diperlukan kuretase dapat dilakukan tanpa menunggu keadaan yang dianggap eutiroid. Pada krisis tiroid pengobatan adalah sama seperti pengobatan krisis tiroid umumnya. Propiltiourasil lebih terpilih dari pada metimazol atau karbimazol, karena kerjanya yang lebih cepat dan kemampuannya menghambat konversi $\mathrm{T}_{4}$ menjadi $\mathrm{T}_{3}$ di jaringan. ${ }^{1}$ Prinsip penangan- an kehamilan mola hidatidosa sendiri adalah gelembung mola harus dievakuasi secepat mungkin. Terdapat dua cara evakuasi yaitu kuret vakum dan histerektomi totalis. Tindakan histerektomi dilakukan hanya untuk golongan berisiko tinggi, yaitu umur $>35$ tahun dengan jumlah anak cukup, sebagai tindakan profilaksis terhadap terjadinya keganasan di uterus. ${ }^{18}$ Pada penderita ini diberikan terapi PTU $100 \mathrm{mg}$ tiga kali sehari dan propanolol $10 \mathrm{mg}$ tiga kali sehari untuk penanganan hipertiroid, serta dilakukan tindakan operasi histerektomi totalis untuk penanganan kehamilan mola hidatidosanya.

Prognosis hipertiroid pada kehamilan mola hidatidosa adalah tergantung dari keadaan pasca evakuasi jaringan mola. Keadaan hipertiroid sekunder ini umumnya akan secara cepat membaik setelah evakuasi jaringan mola. Sekitar $15-20 \%$ dari penderita mola pasca evakuasi dapat mengalami transformasi keganasan menjadi Tumor Trofoblastik Gestasional (TTG). Bila hal ini terjadi maka prognosis akan menjadi buruk. Perlu dilakukan follow up selama satu tahun, tetapi dapat juga sampai dua tahun. Dalam tiga bulan pertama pasca evakuasi, penderita diminta datang untuk kontrol setiap dua minggu. Kemudian dalam tiga bulan berikutnya setiap satu bulan. Selanjutnya dalam enam bulan terakhir setiap dua bulan. Setelah jaringan mola dievakuasi, kadar $\beta$ hCG akan menurun secara perlahanlahan, sampai akhirnya tidak terdeteksi lagi.

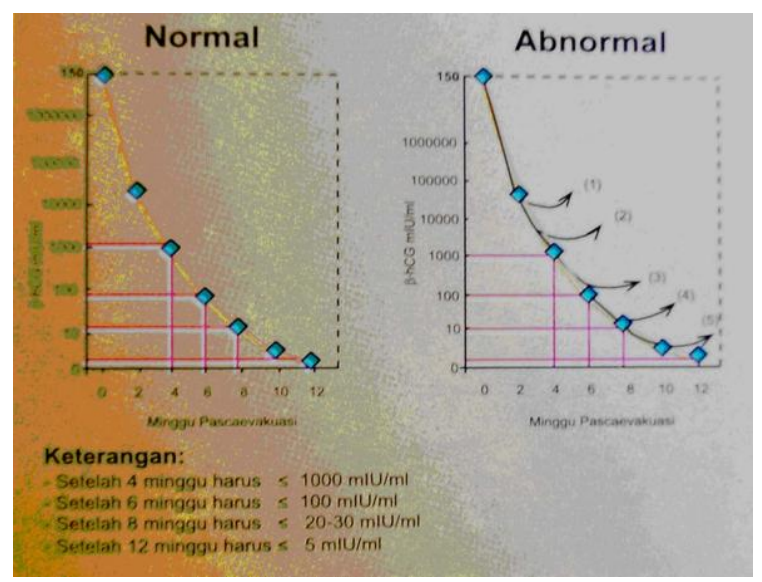

Gambar 3. Kurva regresi $\beta$ hCG normal dan abnormal paska evakuasi kehamilan mola hidatidosa. 
Waktu rata-rata yang diperlukan untuk men-capai kadar normal $(<5 \mathrm{mIU} / \mathrm{ml})$ adalah 12 minggu. Terdapat beberapa jenis kurva regresi, antara lain yang dibuat oleh Mochizuki. Menurut Mochizuki pada keadaan normal kadar $\beta$ hCG akan turun mengikuti kurva regresi (Gambar 3). Terjadi distorsi dari kurva regresi yang normal, berarti terjadi keganasan. Oleh karena itu diagnosis dini TTG dapat ditegakkan dengan memperhatikan kurva regresi ini, dengan syarat penderita harus patuh melakukan follow up. ${ }^{18}$

\section{KESIMPULAN}

Telah dilaporkan sebuah kasus hipertiroid pada kehamilan mola hidatidosa pada seorang perempuan $\mathrm{G}_{3} \mathrm{P}_{2} \mathrm{~A}_{0}$ berumur 42 tahun. Penderita masuk rumah sakit dengan keluhan utama perdarahan jalan lahir disertai keluhan pembesaran kelenjar tiroid, palpitasi, mual, dan muntah. Pemeriksaan laboratorium menunjukkan kadar $\beta$ hCG dan $\mathrm{FT}_{4}$ meningkat, serta TSHs yang rendah. Pemeriksaan penunjang dan histopatologi menyimpulkan suatu kehamilan mola hidatidosa. Penderita diberi pengobatan OAT (obat anti tiroid) dan histerektomi totalis. Prognosis penderita adalah dubia.

\section{DAFTAR PUSTAKA}

1. Kariadi SHKS. Tirotoksikosis pada kehamilan. Dalam: Noer S, Waspadji S, Rachman AM, Lesmana LA, dkk, editor. Buku Ajar Ilmu Penyakit Dalam; Jilid 1,edisi III. Jakarta: Balai Penerbit FKUI; 1996. h. 773-8.

2. Berkowitz RS, Goldstein DP. Chorionic tumors. N Engl J Med 1996 Dec 5;335(23):1740-7.

3. Padmanabhan LD, Mhaskar R, Mhaskar A, Vallikad E. Trophoblastic hyperthyroidism. JAPI [serial online] 2003 Oct [cited 2008 May 28]; 51: 1011-13. Available from: URL:http://lib.bioinfo. $\mathrm{pl} /$ anth:valikad

4. Davies TF, Larsen PR. Thyrotoxicosis. In: Larsen PR, Kronenberg HM, Melmed S, Polonsky KS, editor. Williams textbook of endocrinology. 10th ed. Philadelphia: Saunders by Elsevier; 2003. p. 374-421.
5. Fantz CR, Dagogo-Jack S, Ladenson JH, Gronowski AM. Thyroid function during pregnancy. Clinical Chemistry 1999 Oct 4;45(12);2250-58.

6. Hershman JM. Human chorionic gonadotropin and the thyroid: hyperemesis gravidarum and trophoblastic tumors. Thyroid [serial online] 1999 Jul [cited 2008 May 28]; 9(7):653-7. Available from: URL:http://www.ncbi.nlm.nih. gov/pubmed/10447009

7. Amir S, Osathanondh R, Berkowitz RS, Goldstein DP. Human chorionic gonadotropin and thyroid function in patients with hydatidiform mole. Am J Obstet Gynecol [serial online] 1984 Nov 15 [cited 2008 May 28]; 150(6):723-8. Available from: URL: http://www.ncbi. nlm.nih.gov/pubmed/6496594

8. Norman RJ, Green-Thompson RW, Jialal L, Soutter WP, Pillay NL, Joubert SM. Hyperthyroidism in gestational trophoblastic neoplasia. Clin Endocrinol [serial online] 1981 Oct [cited 2008 May 28]; 15(4):395-401. Available from: URL: http://www.ncbi.nlm.nih.gov/pubmed/73 18191

9. Jameson JL, Weetman AP. Disorders of the thyroid gland. In: Braunwald $\mathrm{E}$, Fauci AS, Kasper DL, Hauser SL, Longo DL, Jameson JL, editors. Harrison's principles of internal medicine. 17th ed. New York: McGraw Hill, Health Professors Division; 2008. p. 2250-55.

10. Kopp P, Jameson JL. Thyroid disorders. In: Jameson JL, Collins FS, editors. Principles of Molecular Medicine. New Jersey: Humana Press; 1998. p. 459-73.

11. Miyai $\mathbf{K}$, Tanizawa $\mathbf{O}$, Yamamoto $\mathbf{T}$, Azukizawa M, Kawai Y. Pituitarythyroid function in trophoblastic disease. Clin Endocrinol [serial online] 1976 [cited 2008 May 28]; 42:254-59. Available from: URL: http://jcem.endojournals.org/cgi/content/abstract/42/2/254

12. Higgins HP, Hershman JM, Kenimer JG, Patillo RA, Bayley TA, Walfish P. The thyrotoxicosis of hydatidiform mole. Ann Intern Med [serial online] 1975 Sep [cited 2008 May 28]; 83(3):307-11. Available from: URL: http://www.ncbi. nlm.nih.gov/pubmed/1180425

13. Ngowngarmratana S, Sunthornthepvarakul T, Kanchanawat S. Thyroid 
function and human chorionic gonadotropin in patients with hydatidiform mole. J Med Assoc Thai [serial online] 1997 Nov [cited 2008 May 28]; 80(11):693-9. Available from: URL: http://www.ncbi.nlm.nih.gov/pubmed/93 85765

14. Leiser AL, Aghajanian C. Evaluation and management of gestational trophoblastic disease. Community Oncology [serial online] 2006 Mar [cited 2008 May 28]; 152-6. Available from: URL: http:// www.communityoncology.net/journal/art icles/0303152.pdf

15. Utiger RD. The thyroid: physiology, thyrotoxicosis, hypothyroidism and the painful thyroid. In: Felig P, Baxter JD, Frohman LA, editors. Endocrinology and Metabolism. 3rd ed. New York: McGraw
Hill; 1995. p. 435-519.

16. Lemon M, Bevan BR, Pennington GW. Thyroid function in tropoblastic disease. $\mathrm{Br} \mathrm{J}$ Obstet Gynaecol [serial online] 1987 Nov [cited 2008 May 28]; 94(11):1084-8. Available from: URL: http://www.ncbi.nlm.nih.gov/pubmed/28 27721

17. Nagataki S, Mizuno M, Sakamoto S, Irie M, Shizume K. Thyroid function in molar pregnancy. Clin Endocrinol [serial online] 1977 [cited 2008 May 28]; 44:254-63 Available from: URL: http:// jcem.endojournals.org/cgi/content/abstra $\mathrm{ct} / 44 / 2 / 254$

18. Martaadisoebrata D. Buku pedoman pengelolaan penyakit trofoblas gestasional. Edisi 1. Jakarta: Penerbit Buku Kedokteran EGC; 2005. h. 1-41. 